\title{
Huaier Extract Induces Apoptosis in Hepatoblastoma Cells Via the MEK/ERK Signaling Pathway
}

\author{
DONG-QING XU ${ }^{1,2}$, XIAO-JUN YUAN ${ }^{1}$, MASAHIRO HIRAYAMA ${ }^{2}$ and HIDEMI TOYODA ${ }^{2}$ \\ ${ }^{1}$ Department of Pediatric Hematology/Oncology, Xin Hua Hospital Affiliated \\ to Shanghai Jiao Tong University School of Medicine, Shanghai, P.R. China; \\ ${ }^{2}$ Department of Pediatrics, Mie University Graduate School of Medicine, Mie, Japan
}

\begin{abstract}
Background/Aim: Huaier extract, whose main active constituent is the proteoglycan, has anti-tumor activity in several types of malignancies. In this study, we aimed to elucidate the effect of Huaier extract in hepatoblastoma cells. Materials and Methods: The effect of Huaier extract on the proliferation of human hepatoblastoma cell lines HepG2 and HuH-6, was examined. Results: Incubation with Huaier extract resulted in a marked, dose-dependent decrease in hepatoblastoma cell viability. Huaier extract induced $S$ phase arrest in hepatoblastoma cells and upregulated the expression of the cell cycle related proteins cyclin D1 and cyclin D3. It also induced apoptosis in hepatoblastoma cells. Additionally, it significantly suppressed the activity of $p-E R K$ and $p-M E K$. Conclusion: Huaier extract inhibits proliferation, and induces cell apoptosis and cell cycle arrest via the MEK-ERK pathway in hepatoblastoma cells. Huaier extract may act as a complementary agent for treating hepatoblastoma.
\end{abstract}

Hepatoblastoma is the most common childhood malignant liver tumor. The incidence peaks in the first two years of life, with the majority of cases presenting by the $5^{\text {th }}$ year of age (1). Complete surgical resection is the mainstay of therapy for hepatoblastoma. Unfortunately, a large number of cases are unresectable at presentation either because they are too large, or multifocal, or due to the close proximity to major vascular structures. This led to a universally gloomy prognosis before neoadjuvant chemotherapy became the standard of care in the treatment of hepatoblastoma (2).

This article is freely accessible online.

Correspondence to: Hidemi Toyoda, MD, Ph.D., Department of Pediatrics; Mie University Graduate School of Medicine, 2-174, Edobashi, Tsu, Mie, Japan. Tel: +81 592321111, Fax: +81 592315127, e-mail: htoyoda@clin.medic.mie-u.ac.jp

Key Words: Hepatoblastoma, MEK/ERK, Huaier extract, apoptosis.
Therefore, identification of novel antitumor agents from natural products is an alternative choice for the management of hepatoblastoma.

In recent years, many Chinese herbs have been gradually discovered to be potential sources of antitumor drugs killing tumor cells less intensely and more naturally (3). Trametes robiniophila Murr. (Huaier) has been applied in traditional Chinese medicine for approximately 1600 years (4); however, its antitumor potency has been discovered only in recent decades and is used as a complementary therapy. The major effective ingredient of this officinal fungi has been identified as proteoglycan, which contains $41.53 \%$ polysaccharides, $12.93 \%$ amino acids, and $8.72 \%$ water (5). A number of studies have shown that Huaier extract exerts potential antitumor effects in many tumor types through proliferation inhibition and apoptosis induction (6-11). In addition, a multicenter, randomized clinical trial has indicated that Huaier extract prolonged significantly recurrence-free survival and reduced extrahepatic recurrence rates in HCC patients after curative resection (12). These studies demonstrated that Huaier extract may be a promising treatment of cancers alone or in combination with other drugs. However, the underlying anti-tumor activity and molecular mechanisms of Huaier extract in hepatoblastoma cells are not yet fully understood.

Cell cycle disturbance, leading to uncontrolled cell proliferation, is one of the most common alterations that occur during tumor generation. Therefore, cell cycle arrest is considered to be an effective approach for eliminating tumor cells (13). Two major checkpoints, one at the $G_{1} / S$ transition and the other at the $\mathrm{G}_{2} / \mathrm{M}$ transition, regulate cell cycle and, therefore, the expression of molecules that regulate transition through these phases of the cell cycle have been investigated in numerous cell types (14). A general process associated with DNA damage is the activation of cell cycle checkpoints and promotion of cell cycle. Cyclicdependent kinases (cdks) are evolutionarily conserved proteins that are essential for cell cycle control. Distinct pairs of cyclins regulate the progression through the various stages 
of the cell cycle. Among these cyclins, cyclin D1 is regarded as an oncogene and is a vital driver of multiple types of human tumors including breast and squamous cell cancers, B-cell lymphoma, myeloma, and parathyroid adenoma (15). In addition to cyclin D1, mitogen-activated protein kinase (MAPK) superfamily members are also associated with increased proliferation, survival, and apoptosis, serving different roles in cellular responses (16). ERK1/2, p38 MAPK, and JNK/SAPK have also been reported to play central roles in the regulation of cyclin D1 expression (17).

Little is known about the molecular mechanisms responsible for the anti-proliferative properties of Huaier extract, and no studies have investigated the potential role of Huaier in human hepatoblastoma cells. Understanding the role and mechanism of Huaier extract will provide useful information for their possible application in cancer therapy. Therefore, in this study, we aimed to explore the antiproliferative effect and mechanisms of Huaier extract in hepatoblastoma cells.

\section{Materials and Methods}

Preparation of Huaier extract. The electuary Huaier ointment was provided by Qidong Gaitianli Medicine Co., Ltd. (Qidong, Jiangsu, PR China). In total, $2 \mathrm{~g}$ of the electuary ointment were dissolved in $20 \mathrm{ml}$ complete medium and sterilized through a $0.22 \mu \mathrm{m}$ filter to obtain a $100 \mathrm{mg} / \mathrm{ml}$ stock solution, which was subsequently stored at $-20^{\circ} \mathrm{C}$.

Cell lines and cell culture. The HepG2 and HuH-6 human hepatoblastoma cell lines were used in this study. They were purchased from the cell bank of RIKEN BRC (Tsukuba, Ibaraki, Japan). The human hepatoblastoma cell line, HuH-6, was cultured in DMEM (\#11885-084, GIBCO, Tsu, Mie, Japan) medium supplemented with $10 \%$ fetal bovine serum (FBS) (\#10100147, GIBCO). The other human hepatoblastoma cell line, HepG2, was cultured in DMEM (\#11995-065, GIBCO) medium supplemented with 10\% FBS (\#10100147, GIBCO). Cells were incubated in a humidified atmosphere at $37^{\circ} \mathrm{C}$ with $5 \% \mathrm{CO}_{2}$.

Antibodies and reagents. The following antibodies and reagents were used in this study: anti-MEK (\#9122, Cell Signaling, Tokyo, Chiyodaku, Japan), anti-ERK1/2 (\#9102, Cell Signaling), phosphoMEK (\#9121, Cell Signaling), phospho-ERK1/2 (\#9106, Cell Signaling), anti-cleaved PARP (\#5625, Cell Signaling), anti-PARP (\#9532, Cell Signaling), cell cycle regulation kit (\#9932, Cell Signaling).

Cell morphology. The hepatoblastoma cells were incubated with 2 or $5 \mathrm{mg} / \mathrm{ml}$ Huaier extract for $48 \mathrm{~h}$. In order to identify the morphological changes of the hepatoblastoma cells, the cells were observed under an Olympus light microscope (CX31-72C02; Olympus Corporation, Tokyo, Japan), and photomicrographs were captured using an Olympus digital camera (DP72; Olympus Corporation).

MTT assay. MTT reagent was obtained from Sigma Aldrich (Tsu, Mie, Japan). Cells $\left(5 \times 10^{3}\right)$ were seeded in $100 \mu \mathrm{l}$ medium in 96 wells plates and pre-incubated for $6 \mathrm{~h}$ before the addition of the inhibitors. MTT $(20 \mu \mathrm{l}, 5 \mathrm{mg} / \mathrm{ml})$ was added into each well. After $3.5 \mathrm{~h}$ incubation in a humidified atmosphere at $37^{\circ} \mathrm{C}$ with $5 \% \mathrm{CO}_{2}$, the culture media was removed, and DMSO $(150 \mu \mathrm{l})$ was added. The plates were shaken vigorously for $15 \mathrm{~min}$ and the absorbance at $590 \mathrm{~nm}$ was measured using multi-spectrophotometer (Viento, Dainippon, Japan). The optical density was used to determine cell viability. The results are expressed as mean $\pm \mathrm{SD}$ from 3 independent experiments.

Western blotting. Cellular extracts were obtained as previously reported (18). The proteins $(20 \mu \mathrm{g} / \mathrm{lane})$ were analyzed on $7.5,10$ or $15 \%$ sodium dodecyl sulfate-polyacrylamide gel electrophoresis followed by semi-dry transfer to PVDF membrane (Invitrogen, Carlsbad, CA, USA). PVDF membranes were pretreated with 5\% non-fat dry milk in TBST containing $0.1 \%$ Tween-20 and incubated with primary antibody $(1: 1000-3000)$ at $4^{\circ} \mathrm{C}$ overnight. The membrane was then washed 3 times with TBST and incubated with horseradish peroxidase-conjugated secondary antibody (1:10003000 ) for $1 \mathrm{~h}$ at room temperature $\left(28-35^{\circ} \mathrm{C}\right)$. To detect phosphorylated proteins, transferred PVDF blots were pretreated with PVDF Blocking Reagent (TOYOBO, Osaka, Japan) for $1 \mathrm{~h}$, and incubated with primary and then with secondary antibody (1: 3000-6000) which were diluted with Can Get Signal ${ }^{\circledR}$ Immunoreaction Enhancer Solution (TOYOBO) at room temperature for $1 \mathrm{~h}$. After washing three times again, bound antibodies were detected by using Western Lightening Chemiluminescence Reagent Plus (Perkin Elmer Life Science, Boston, MA, USA), and visualized on LAS-3000 mini (FUJIFILM).

Cell cycle analysis. Cell cycle analysis was performed after treatment with/without Huaier extract for $24 \mathrm{~h}$. Cells $\left(2 \times 10^{6}\right)$ were harvested and fixed in $99.5 \%$ ethanol over night at $-20^{\circ} \mathrm{C}$, followed by incubation with $500 \mu \mathrm{l}$ propidium iodide (PI) Triton X-100 solution containing RNase A at room temperature $\left(28-35^{\circ} \mathrm{C}\right)$ for 30 min in the dark. Then the DNA content was analyzed immediately with FACS, analyzed by using the ModFitLT software.

Statistical analysis. Statistical analysis was performed using SPSS (IBM Corporation, Tsu, Mie, Japan). Statistical significance of differences between groups was evaluated using Student's $t$-test and two-way ANOVA. A $p$-value $<0.05$ was considered to be statistically significant.

\section{Results}

Huaier extract inhibited proliferation and caused morphological changes of HepG2 and HuH-6 cells. To evaluate the effect of Huaier extract on HepG2 and HuH-6 hepatoblastoma cells, we measured cell viability using the MTT assay after the cells were treated with various concentrations of Huaier for 24, 48 and $72 \mathrm{~h}$. As shown in Figure $1 \mathrm{~A}$ and $\mathrm{B}$, Huaier significantly inhibited viability of both HepG2 (Figure 1A) and HuH-6 (Figure 1B) in a dosedependent manner. HepG2 cells were more sensitive than HuH-6. Treatment with $8 \mathrm{mg} / \mathrm{ml}$ of Huaier for $72 \mathrm{~h}$ decreased the viability of HepG 2 and HuH- 6 cells by almost $97 \%$ and $72 \%$, respectively. The morphological changes of 
A

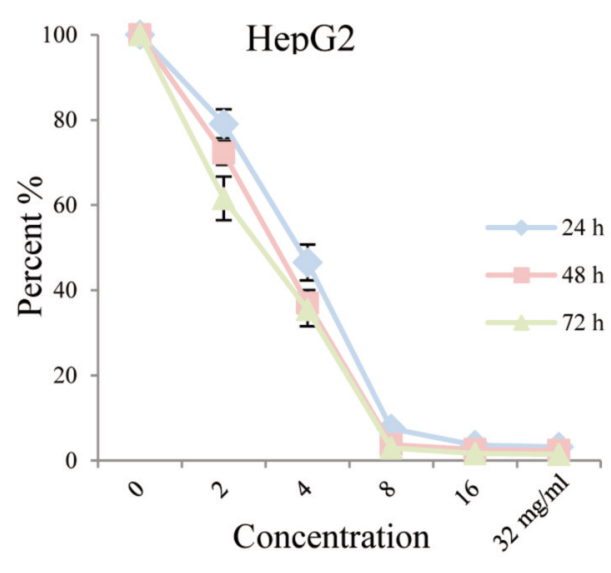

C

HepG2

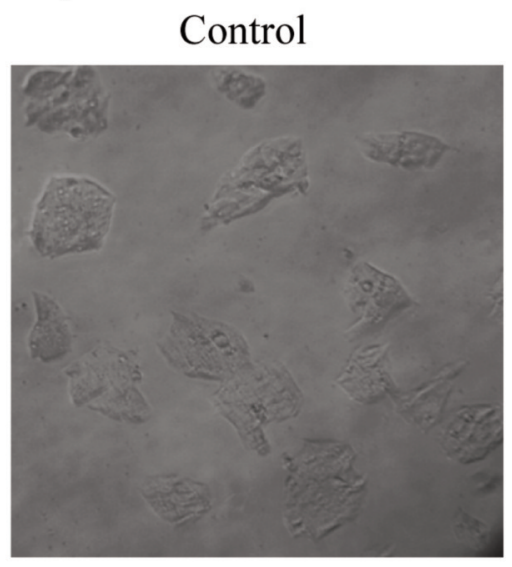

HuH-6

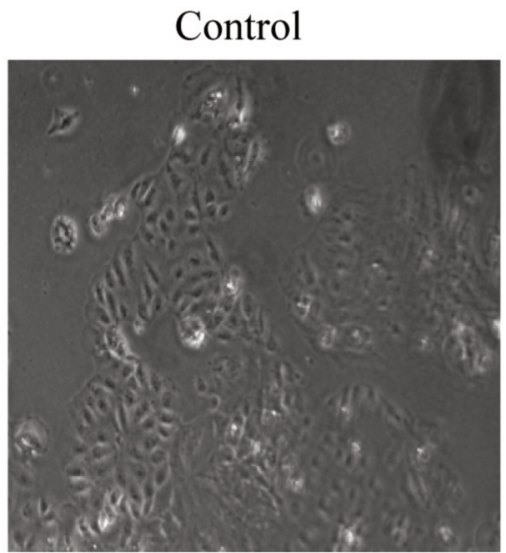

B

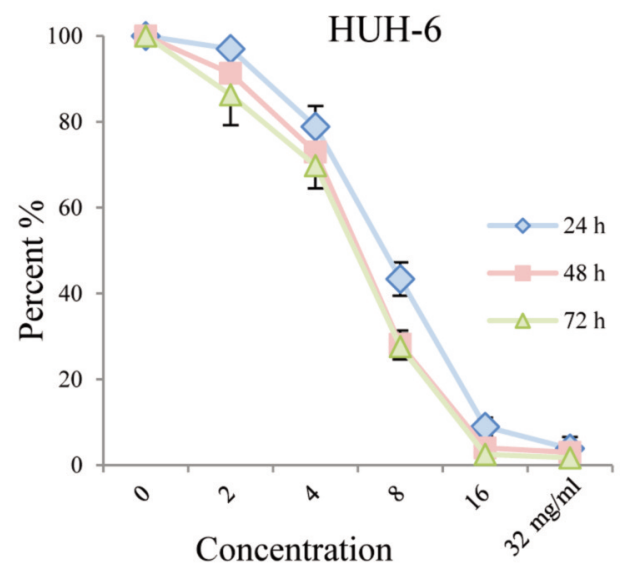

$4 \mathrm{mg}-48 \mathrm{~h}$

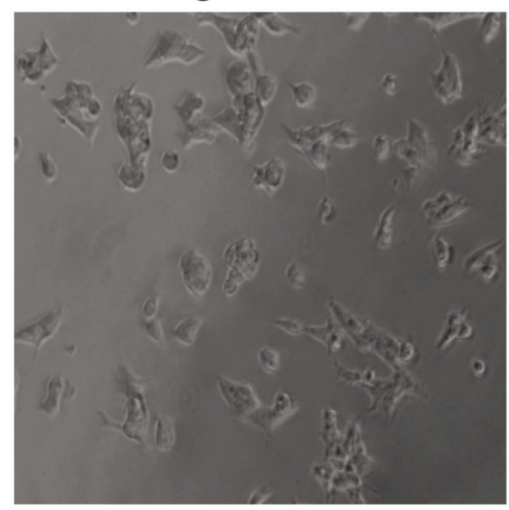

$4 \mathrm{mg}-48 \mathrm{~h}$

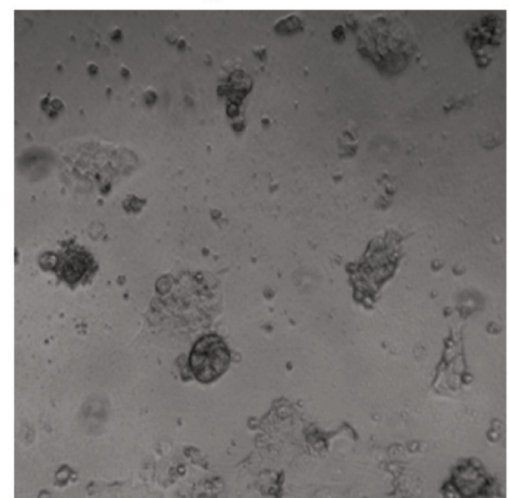

Figure 1. Huaier extract suppressed cell viability of HepG2 and HuH-6 cells. The effect of Huaier extract on cell viability was measured by the MTT assay. (A) HepG2 and (B) HuH-6 cells were treated with Huaier extract for 24, 48 and $72 \mathrm{~h}$. Huaier extract significantly inhibited cell viability of both cell lines in a dose-dependent manner. The experiments were performed in triplicate and data is presented as the mean $\pm S D$ of three separate experiments. (B) Phase-contrast images revealing the morphologies of HepG2 and HuH-6 cells prior and after treatment with $4 \mathrm{mg} / \mathrm{ml} \mathrm{Huaier}$ for 48 h. Magnification 200x. 
A

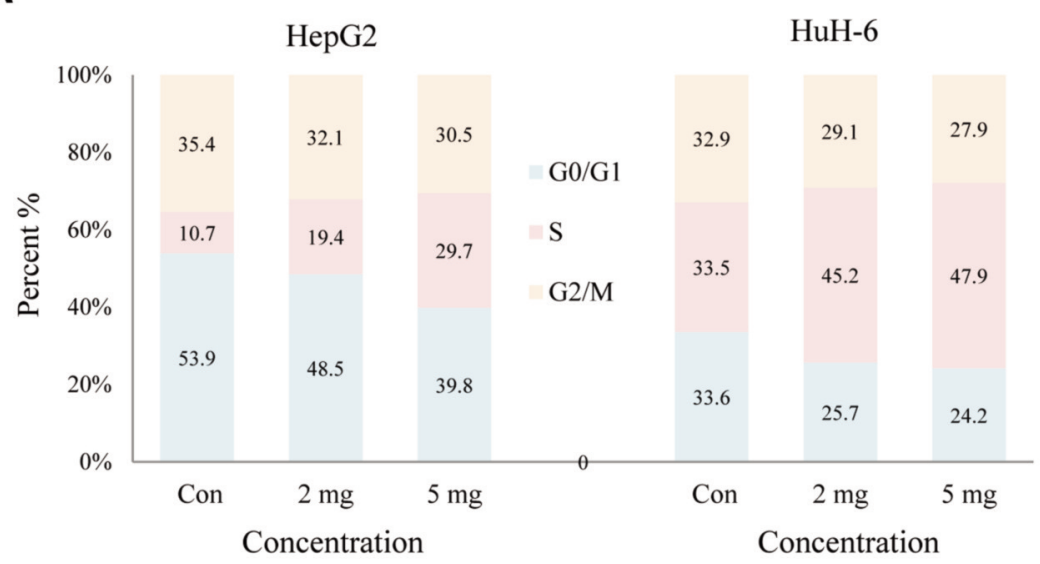

B HepG2 HuH-6

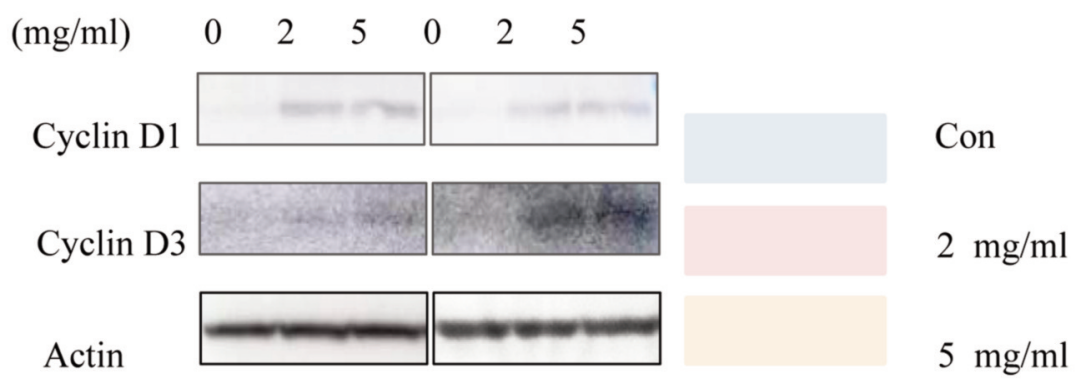

HepG2

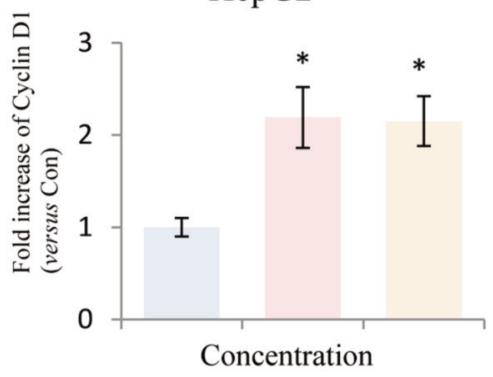

HepG2

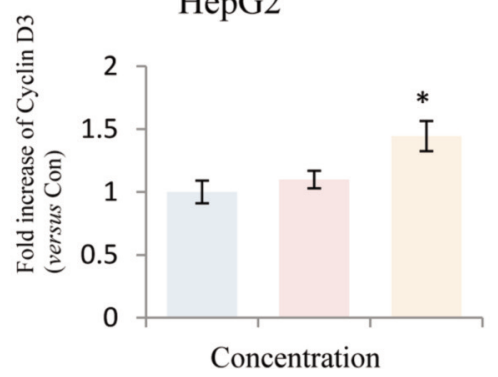

HuH-6

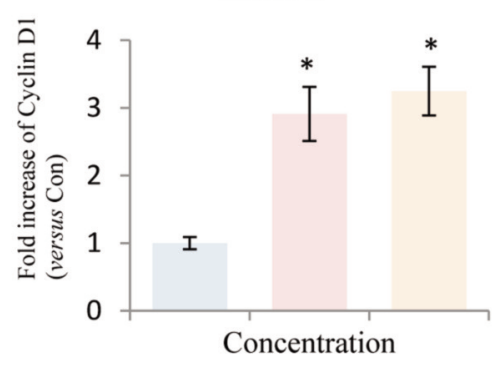

HuH-6

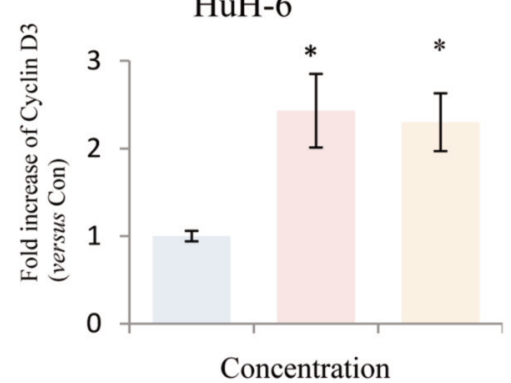

Figure 2. Huaier extract induced S phase accumulation in HepG2 and HuH-6 cells. A. Treatment of HepG2 and HuH-6 cells treated with/without Huaier extract $(0,2,5 \mathrm{mg} / \mathrm{ml})$ for $24 \mathrm{~h}$ was followed by analysis of cell cycle phase distribution, as described in Materials and Methods. Cells were stained with PI for 30 min followed by FACScan flow cytometer analysis. B. HepG2 and HuH-6 cells were incubated in RPMI1640+10\% FBS with/without Huaier extract $(0,2,5 \mathrm{mg} / \mathrm{ml})$ for $24 \mathrm{~h}$. Cyclin D1, Cyclin D3 and actin were detected by western blot. The intensity of Cyclin D1and Cyclin D3 was quantified by ImageJ. After normalization to actin, the fold increase of Cyclin Dland Cyclin D3 versus the control was compared. Data represent mean \pm SD. *Represents $p<0.05$. 
A

HepG2 HuH-6

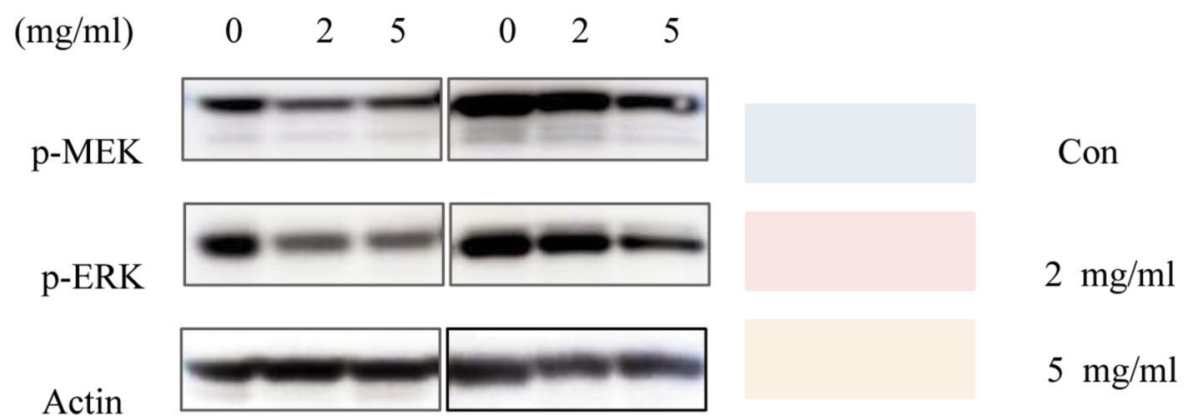

B

HepG2

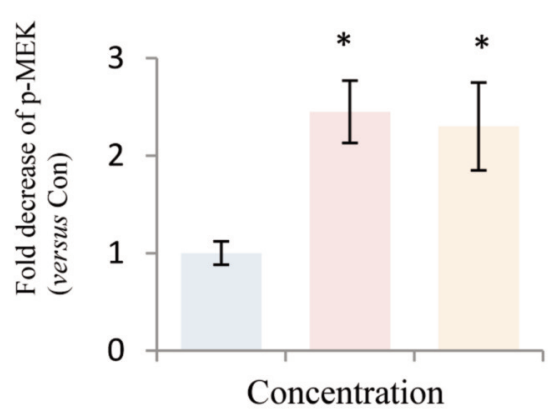

HepG2

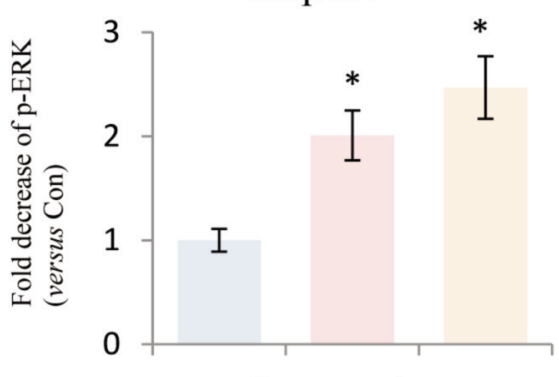

Concentration
HuH-6

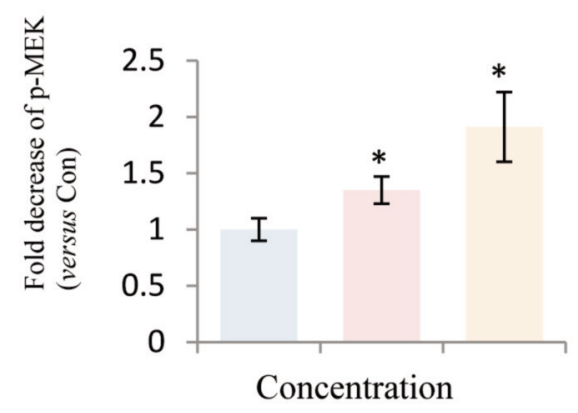

HuH-6

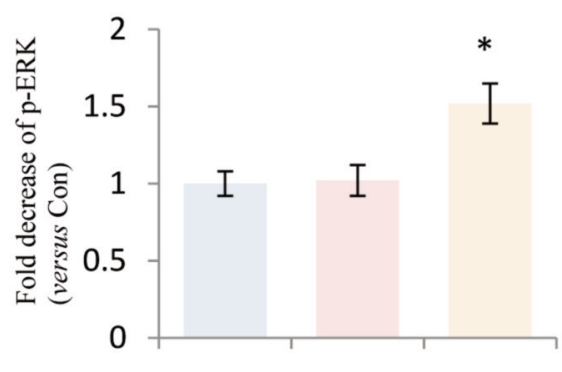

Concentration

Figure 3. Effect of Huaier extract on MEK/ERK signaling in HepG2 and HuH-6 cells. A. HepG2 and HuH-6 cells were incubated in RPMI1640+10\% FBS with/without Huaier extract $(0,2,5 \mathrm{mg} / \mathrm{ml})$ for $24 \mathrm{~h} . \mathrm{p}$-MEK, $\mathrm{p}$-ERK and actin were detected by western blot as described in Materials and Methods. B. The intensity of p-MEK and p-ERK was quantified by ImageJ. After normalization to actin, the fold decrease of p-MEK and p-ERK versus the control was compared. Data represent mean \pm SD. *Represents $p<0.05$.

HepG2 and HuH-6 cells after treatment with Huaier for 48 $\mathrm{h}$ are shown in Figure 1C. Compared with the untreated cells, the majority of the Huaier-treated HuH-6 cells became enlarged, irregular, spinous and had a vacuolized cytoplasm, while numerous HepG2 cells became extremely elongated and showed the special "wiredrawing" morphology. These morphological changes demonstrated cell damage after Huaier treatment.
Huaier treatment induced S-phase accumulation in HepG2 and HuH-6 cells. To explore the mechanisms responsible for the inhibitory effect, we investigated the impact of Huaier extract on the distribution of cells in the various phases of the cell cycle. As shown in Figure 2A, Huaier extract induced $S$ phase accumulation in HepG2 and HuH-6 cells. The progression from $\mathrm{G} 1$ to $\mathrm{S}$ phase in mammalian cells is thought to be regulated by D-type cyclins $(13,15)$. Thus, we 
A

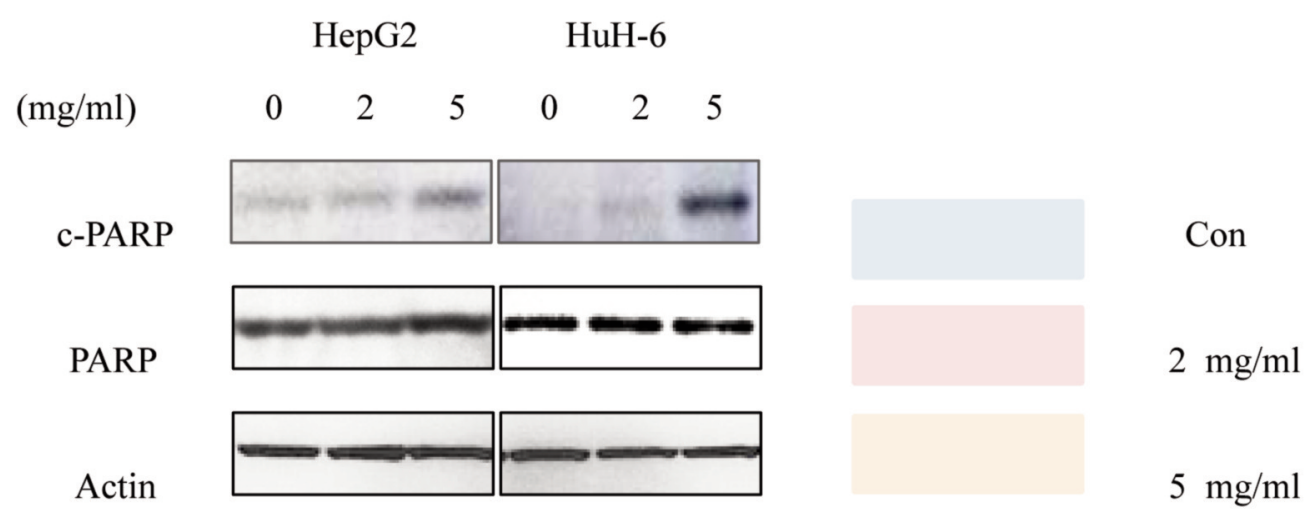

B
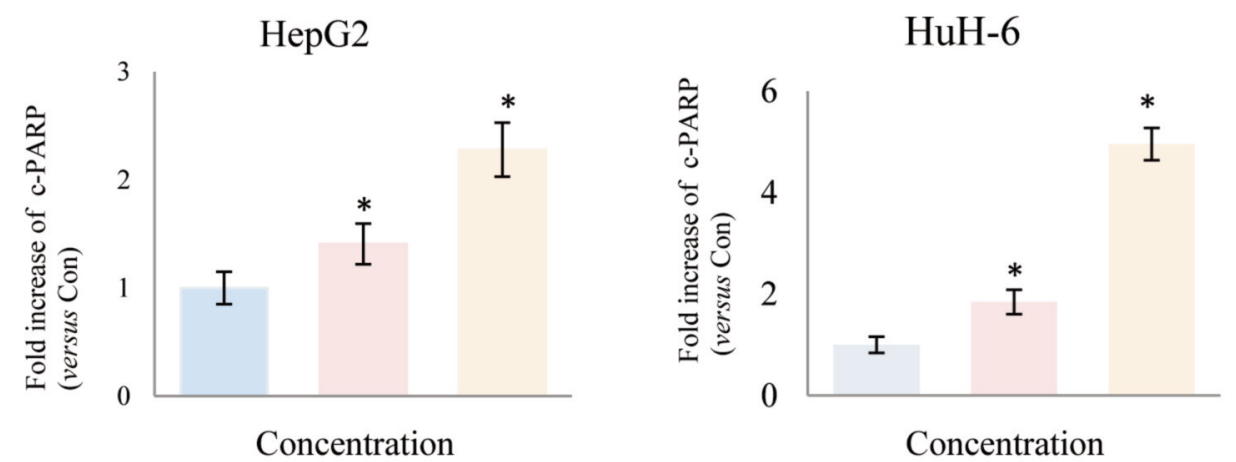

Figure 4. Effect of Huaier extract on apoptosis in HepG2 and HuH-6 cells. A. HepG2 and HuH-6 cells were incubated in RPMI1640+10\% FBS with/without Huaier extract $(0,2,5 \mathrm{mg} / \mathrm{ml})$ for $48 \mathrm{~h}$. Expression of PARP, cleaved PARP and actin were detected by western blot as described in methods and material. B. The intensity of PARP and cleaved PARP was quantified by ImageJ. After normalization to actin, the fold increase of cleaved PARP versus the control was compared. Data represent mean $\pm S D$. *Represents $p<0.05$.

examined expression of the proteins related to cell cycle regulation by western blot. In HepG2 and HuH-6 cells, cyclin D1 and cyclin D3 were upregulated following treatment with Huaier extract (Figure 2B), consistent with the accumulation of cells in $\mathrm{S}$ phase.

Huaier extract suppressed MEK/ERK signaling in HepG2 and HuH-6 cells. Since the anti-tumor effect is usually closely correlated with down-regulation of cell survival signaling pathways, we hypothesized that Huaier extract treatment may result in the inhibition of the signaling pathways involved in cell survival. MAPK has been shown to be involved in the induction of cell cycle related cyclin Ds in many types of cancer (17). Given that treatment with Huaier extract upregulated the expression of cyclin D1 and cyclin D3, we examined the expression of MAPK related proteins after treatment of hepatoblastoma cells with Huaier extract. Treatment of HepG2 and HuH-6 cells with different concentrations of Huaier extract resulted in a significant dose-dependent decrease in the phosphorylation of MEK and ERK in hepatoblastoma cells (Figure 3). This finding indicates that Huaier extract may promote the expression of cyclin D1 and cyclin D3 by inactivating the MEK-ERK signaling pathway.

Huaier extract induced apoptosis in HepG2 and HuH-6 cells. It is well known that the induction of apoptosis is a promising target in cancer therapy. To demonstrate the apoptosis effect of Huaier extract, we analyzed the expression of apoptosis related proteins using western blot. After treatment of HepG2 and HuH-6 cells with different concentrations of Huaier extract for $48 \mathrm{~h}$, as shown in Figure 4, expression of cleaved-PARP was significantly upregulated compared to untreated control cells, demonstrating that Huaier extract induced apoptosis in HepG2 and HuH-6 cells. 


\section{Discussion}

TCM has gained significant attention following findings on its role in cancer prevention and treatment $(19,20)$. Huaier extract has been used in China for approximately 1600 years (21). Compared to the conventional chemotherapy and radiotherapy which are not only cytotoxic to tumor cells, but are also harmful to normal cells, Huaier extract, as a complementary antitumor agent, has acquired increasing attention because of its antitumor effects and low toxicity $(19,22)$. Huaier extract has been investigated in patients and found to provide clinical benefits. Zhang et al. have found that Huaier granule could prolong the DFS, reduce serum tumor markers and improve the quality of life of breast cancer patients (23). In the present study, the antitumor effect and underlying mechanisms of Huaier extract in hepatoblastoma cells were investigated.

We obtained data indicating that treatment of hepatoblastoma cells with $0,2,4,8,16 \mathrm{mg} / \mathrm{ml}$ of Huaier extract inhibited their proliferation and induced apoptosis. It was also demonstrated that Huaier extract inhibited cell viability and induced morphological changes to cells. The MTT assay also revealed that the Huaier extract reduced the viability of hepatoblastoma cells in a dose-dependent manner. In addition, certain apoptotic morphological alterations were observed following treatment with Huaier extract, which indicated cell damage.

Previous studies have indicated that Huaier extract induces cell cycle arrest and apoptosis in a number of cell types, such as hepatocarcinoma, melanoma, ovarian cancer and breast cancer cells (24-27). The results from the present study revealed that the proportion of S phase hepatoblastoma cells gradually increased, consistent with the upregulation of the cell-cycle proteins cyclin D1 and cyclin D3. These results suggest that Huaier extract suppresses the proliferation of hepatoblastoma cells through the upregulation of cell cycle proteins to induce cell cycle arrest at the $S$ phase. It is well known that the induction of apoptosis is a promising cancer treatment strategy. Furthermore, we found that treatment of cells with Huaier extract increased apoptosis compared to untreated control cells. It has been shown that many human tumors and cell lines derived from tumor cells display constitutive activation of the MEK/ERK signaling pathway, which regulates apoptosis and cell cycle progression (28). As shown in present study, the phosphorylation of MEK and ERK in hepatoblastoma cells was reduced by Huaier extract. This finding indicates that Huaier extract may induce cellcycle arrest and apoptosis through inactivation of the MEKERK signaling pathway.

In summary, our results showed that Huaier extract could inhibit cell proliferation by inhibiting the MEK-ERK signaling pathway to induce apoptosis and cell-cycle arrest in hepatoblastoma cells. These results contribute to the understanding of the anticancer activity of Huaier extract. Therefore, Huaier extract may be used as a novel complementary medicine in hepatoblastoma treatment.

\section{Conflicts of Interest}

The Authors have no conflicts of interest to declare regarding this study.

\section{Authors' Contributions}

Xiao-jun Yuan designed the study; Dong-qing Xu performed experiments, analyzed the data and wrote a draft of the manuscript; Masahiro Hirayama and Hidemi Toyoda revised the manuscript.

\section{Acknowledgements}

The work was funded by the Japanese Ministry of Health (15K096500K).

\section{References}

1 Stafman LL, Mruthyunjayappa S, Waters AM, Garner EF, Aye JM, Stewart JE, Yoon KJ, Whelan K, Mroczek-Musulman E and Beierle EA: Targeting pim kinase as a therapeutic strategy in human hepatoblastoma. Oncotarget 9(32): 22665-22679, 2018. PMID: 29854306. DOI: 10.18632/oncotarget.25205

2 Tannuri AC, Cristofani LM, Teixeira RA, Odone Filho V and Tannuri U: New concepts and outcomes for children with hepatoblastoma based on the experience of a tertiary center over the last 21 years. Clinics (Sao Paulo) 70(6): 387-392, 2015. PMID: 26106955. DOI: 10.6061/clinics/2015(06)01

3 McPherson L, Cochrane S and Zhu X: Current usage of traditional chinese medicine in the management of breast cancer: A practitioner's perspective. Integr Cancer Ther 15(3): 335-342, 2016. PMID: 26420777. DOI: 10.1177/1534735415607656

4 Ayeka PA: Potential of mushroom compounds as immunomodulators in cancer immunotherapy: A review. Evid Based Complement Alternat Med 2018: 7271509, 2018. PMID: 29849725. DOI: $10.1155 / 2018 / 7271509$

5 Pan J, Yang C, Jiang Z and Huang J: Trametes robiniophila murr: A traditional chinese medicine with potent anti-tumor effects. Cancer Manag Res 11: 1541-1549, 2019. PMID: 30863164. DOI: 10.2147/CMAR.S193174

6 Chen Y, Wu H, Wang X, Wang C, Gan L, Zhu J, Tong J and Li $\mathrm{Z}$ : Huaier granule extract inhibit the proliferation and metastasis of lung cancer cells through down-regulation of mtdh, jak2/stat3 and mapk signaling pathways. Biomed Pharmacother 101: 311321, 2018. PMID: 29499405. DOI: 10.1016/j.biopha. 2018.02 .028

7 Hu B, Yan W, Wang M, Cui X, Hu Y, Chen Q, Zhang Y, Qi X and Jiang $\mathrm{J}$ : Huaier polysaccharide inhibits the stem-like characteristics of eralpha-36(high) triple negative breast cancer cells via inactivation of the eralpha-36 signaling pathway. Int $\mathrm{J}$ Biol Sci 15(7): 1358-1367, 2019. PMID: 31337967. DOI: 10.7150/ijbs.27360

8 Wang W, Wang X, Li C, Chen T, Zhang N, Liang Y, Li Y, Zhang H, Liu Y, Song X, Zhao W, Chen B, Wang L and Yang Q: Huaier 
suppresses breast cancer progression via linc00339/mir4656/csnk2b signaling pathway. Front Oncol 9: 1195, 2019. PMID: 31781497. DOI: 10.3389/fonc.2019.01195

9 Wang Y, Lv H, Xu Z, Sun J, Ni Y, Chen Z and Cheng X: Huaier n-butanol extract suppresses proliferation and metastasis of gastric cancer via c-myc-bmi1 axis. Sci Rep 9(1): 447, 2019. PMID: 30679589. DOI: 10.1038/s41598-018-36940-w

10 Wei C, Liu Z, Li L, Zhang Y, Fang Z and Fan Y: The anticancer effect of huaier extract in renal cancer 786-o cells. Pharmacology 102(5-6): 316-323, 2018. PMID: 30296782. DOI: $10.1159 / 000492935$

11 Xie J, Zhuan B, Wang H, Wang Y, Wang X, Yuan Q and Yang Z: Huaier extract suppresses non-small cell lung cancer progression through activating nlrp3-dependent pyroptosis. Anat Rec (Hoboken), 2019. PMID: 31692261. DOI: 10.1002/ar.24307

12 Chen Q, Shu C, Laurence AD, Chen Y, Peng BG, Zhen ZJ, Cai JQ, Ding YT, Li LQ, Zhang YB, Zheng QC, Xu GL, Li B, Zhou WP, Cai SW, Wang XY, Wen H, Peng XY, Zhang XW, Dai CL, Bie P, Xing BC, Fu ZR, Liu LX, Mu Y, Zhang L, Zhang QS, Jiang B, Qian HX, Wang YJ, Liu JF, Qin XH, Li Q, Yin P, Zhang ZW and Chen XP: Effect of huaier granule on recurrence after curative resection of hcc: A multicentre, randomised clinical trial. Gut 67(11): 2006-2016, 2018. PMID: 29802174. DOI: 10.1136/gutjnl-2018-315983

13 Otto T and Sicinski P: Cell cycle proteins as promising targets in cancer therapy. Nat Rev Cancer 17(2): 93-115, 2017. PMID: 28127048. DOI: $10.1038 /$ nrc. 2016.138

14 Aleem E and Arceci RJ: Targeting cell cycle regulators in hematologic malignancies. Front Cell Dev Biol 3: 16, 2015. PMID: 25914884. DOI: 10.3389/fcell.2015.00016

15 Qie S and Diehl JA: Cyclin d1, cancer progression, and opportunities in cancer treatment. J Mol Med (Berl) 94(12): 1313-1326, 2016. PMID: 27695879. DOI: 10.1007/s00109-016$1475-3$

$16 \mathrm{Xu}$ DQ, Toyoda H, Qi L, Morimoto M, Hanaki R, Iwamoto S, Komada $\mathrm{Y}$ and Hirayama M: Induction of mek/erk activity by azd8055 confers acquired resistance in neuroblastoma. Biochem Biophys Res Commun 499(3): 425-432, 2018. PMID: 29571732. DOI: $10.1016 /$ j.bbrc.2018.03.143

17 Pandey S, Talukdar I, Jain BP, Tanti GK and Goswami SK: Gsk3beta and erk regulate the expression of $78 \mathrm{kda} \operatorname{sg} 2 \mathrm{na}$ and ectopic modulation of its level affects phases of cell cycle. Sci Rep 7(1): 7555, 2017. PMID: 28790387. DOI: 10.1038/s41598017-08085-9

18 Xu DQ, Toyoda H, Yuan XJ, Qi L, Chelakkot VS, Morimoto M, Hanaki R, Kihira K, Hori H, Komada Y and Hirayama M: Antitumor effect of azd8055 against neuroblastoma cells in vitro and in vivo. Exp Cell Res 365(2): 177-184, 2018. PMID: 29499203. DOI: $10.1016 /$ j.yexcr.2018.02.032
19 Hermawan A and Putri H: Current report of natural product development against breast cancer stem cells. Int J Biochem Cell Biol 104: 114-132, 2018. PMID: 30266524. DOI: 10.1016/ j.biocel.2018.09.012

20 Wang J, Yang S, Cai X, Dong J, Chen Z, Wang R, Zhang S, Cao H, Lu D, Jin T, Nie Y, Hao J and Fan D: Berberine inhibits egfr signaling and enhances the antitumor effects of egfr inhibitors in gastric cancer. Oncotarget 7(46): 76076-76086, 2016. PMID: 27738318. DOI: 10.18632 /oncotarget.12589

21 Song X, Li Y, Zhang H and Yang Q: The anticancer effect of huaier (review). Oncol Rep 34(1): 12-21, 2015. PMID: 25955759. DOI: 10.3892/or.2015.3950

22 McCulloch M, See C, Shu XJ, Broffman M, Kramer A, Fan WY, Gao J, Lieb W, Shieh K and Colford JM, Jr.: Astragalus-based chinese herbs and platinum-based chemotherapy for advanced non-small-cell lung cancer: Meta-analysis of randomized trials. J Clin Oncol 24(3): 419-430, 2006. PMID: 16421421. DOI: 10.1200/JCO.2005.03.6392

23 Zhang Y, Wang X and Chen T: Efficacy of huaier granule in patients with breast cancer. Clin Transl Oncol 21(5): 588-595, 2019. PMID: 30276759. DOI: 10.1007/s12094-018-1959-4

24 Wang J, Wang X, Chen T, Jiang L and Yang Q: Huaier extract inhibits breast cancer progression through a lncrna-h19/mir-6755p pathway. Cell Physiol Biochem 44(2): 581-593, 2017. PMID: 29145193. DOI: $10.1159 / 000485093$

$25 \mathrm{Xu} \mathrm{Z}$, Zheng G, Wang Y, Zhang C, Yu J, Teng F, Lv H and Cheng $\mathrm{X}$ : Aqueous huaier extract suppresses gastric cancer metastasis and epithelial to mesenchymal transition by targeting twist. J Cancer 8(18): 3876-3886, 2017. PMID: 29151976. DOI: $10.7150 /$ jca.20380

26 Li Y, Qi W, Song X, Lv S, Zhang H and Yang Q: Huaier extract suppresses breast cancer via regulating tumor-associated macrophages. Sci Rep 6: 20049, 2016. PMID: 26831282. DOI: 10.1038/srep20049

27 Zhang F, Zhang Z and Liu Z: Effects of huaier aqueous extract on proliferation and apoptosis in the melanoma cell line a875. Acta Histochem 115(7): 705-711, 2013. PMID: 23601357. DOI: 10.1016/j.acthis.2013.02.010

28 Jacquel A, Luciano F, Robert G and Auberger P: Implication and regulation of ampk during physiological and pathological myeloid differentiation. Int J Mol Sci 19(10), 2018. PMID: 30274374. DOI: 10.3390/ijms19102991
Received February 19, 2020

Revised May 10, 2020

Accepted May 11, 2020 